\title{
Statistical Reflections Regarding the Significance of the Microscopic Examination in the Diagnosis of Mammary and Abdominal Neoplasias in Cats
}

\author{
Elena GAVRILAȘ ${ }^{1}{ }^{*}$, Vasile VULPE ${ }^{1}$ \\ Faculty of Veterinary Medicine of Iasi, Ion Ionescu de la Brad University of Agricultural Sciences and \\ Veterinary Medicine, Mihail Sadoveanu Street, no.8, 700489 \\ *corresponding author: ena_2987@yahoo.com
}

Bulletin UASVM Veterinary Medicine 76(1)/2019

Print ISSN 1843-5270; Electronic ISSN 1843-5378

doi:10.15835/buasvmcn-vm: 2018.0022

\begin{abstract}
76 cats were clinical examined for mammary and abdominal neoplasias. In 41 cats were performed microscopic examination. Regarding the location of the primary tumors 70 cats had mammary tumors. Isolated, six cases of primary non-mammary tumors were diagnosed following necropsy and histopathology. Following cytopathological and histopathological examinations, 14 tumor types were identified, of which 3 benign and 11 malignant. Benign tumoral types consisted of lipoma, vesical leiomyoma and mammary adenoma. Diagnosed malignant cases consisted of simple mammary adenocarcinoma, solid adenocarcinoma, compact adenocarcinoma, hepatic cholangiocarcinoma, compact carcinoma, mixed pulmonar bronchioloalveolar carcinoma, hemangiosarcoma, mammary comedocarcinoma, solid carcinoma and mixed adenocarcinoma.
\end{abstract}

Keywords: cat, examination, mammary, microscopic, neoplasias

\section{Introduction}

The importance of the neoplastic disease, brought forth by the clinical and anatomical diversity, comes from the connection between human and veterinary oncology, under the coordination of the comparative aspects. This fact created the possibility of studying and understanding the relationship between veterinary and human cancer (Hanahan and Weinberg, 2011; Hayes and Mooney, 1985; Madewell and Theilea, 1987; Weijer et al., 1972).

To understand cancer, we must realize that it is not a simple or a freestanding disease, rather the term "cancer" is an umbrella term that describes a large number of pathological processes whose only common feature is uncontrolled cell growth and proliferation (Argyle and Khanna, 2007; Fidler, 2003; Hanahan and Weinberg, 2011; Mendoza and Khanna, 2009). The prevalence of cancer in pets is growing steadily, for a variety of reasons, some still being studied, and it is one of the major morbidity and mortality causes in cats and dogs (Barbara, 2008; Biller et al., 2016; Dobson and Lascelles, 2011; Misdorp et al., 1991). Pets with spontaneous cancer development provide an excellent opportunity to investigate many aspects regarding the disease etiology and treatment (Baba, 2002; Balint, 2010; Kusewitt and Rush, 2007).

\section{Materials and Methods}

76 cats were clinical examined for mammary and abdominal neoplasias. In 41 cats were performed microscopic examination $(53,95 \%$ from total) (Figure 1) (Gavrilaș, 2016).

The certainty diagnosis of the tumoral processes in the studied cases was performed on the basis of the necropsy examination, followed by the microscopichistopathological and electronomicroscopic examination (Figure 2) (Gavrilaș, 2016). 


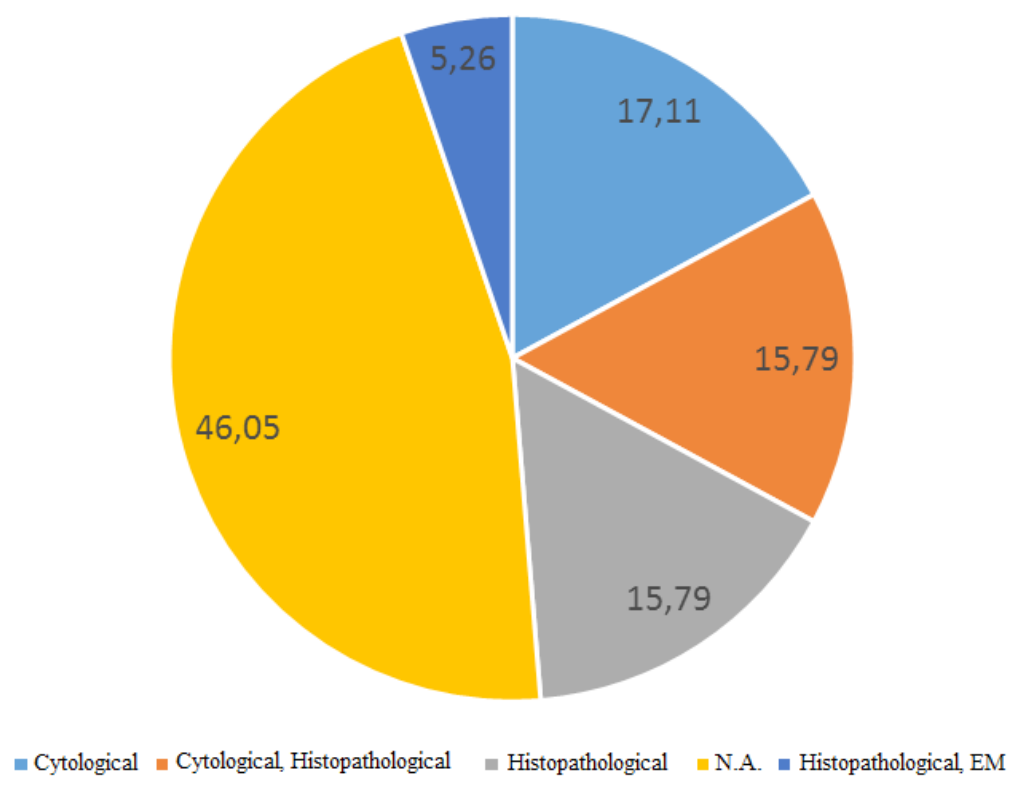

Figure 1. Distribution of feline patients according to performed microscopic exams, expressed as absolute value (n.a - not available, EM - electronomicroscopy).

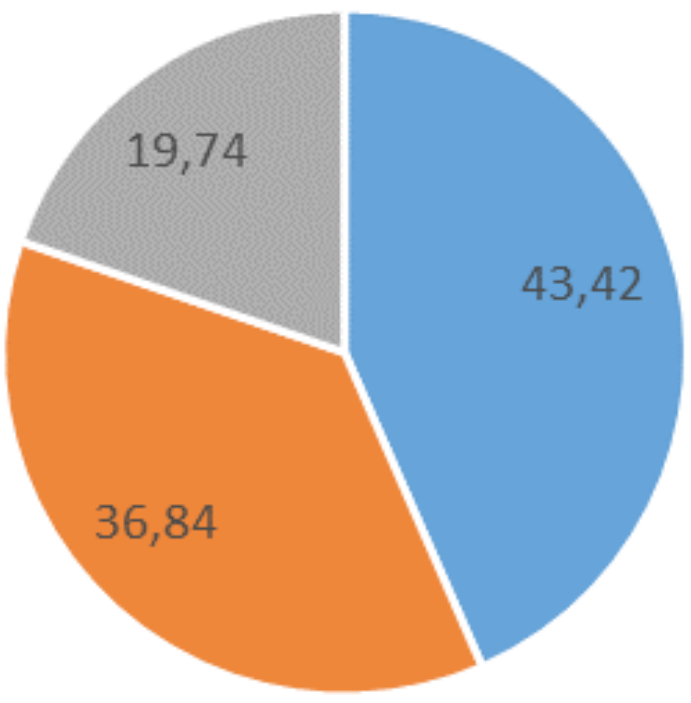

$\mathrm{x} \square$ n.a. $\mathbf{0} 0$

Figure 2. Case distribution according to necropsy exam, expressed as relative value (\%) ( $\mathrm{x}$ - cased with necropsies, n.a. - deceased without necropsy, 0 - viable cases).

\section{Results and discussions}

Regarding the location of the primary tumors 70 cats had mammary tumors $(92,11 \%$ from total). Isolated, six cases of primary non-mammary tumors were diagnosed following necropsy and histopathology (Figure 3) (Gavrilaș, 2016).

Following cytopathological and histopathological examinations, 14 tumor types were identified, 
of which 3 benign and 11 malignant (Figure 4) (Gavrilaș, 2016).

Acknowledging the importance of pets and the increasingly close human - animal bonds, it is to be appreciated the fact that the care of the veterinarian towards his patient and his ability to diagnose and heal are equally important, these qualities being equally valued by the pet owners (Weijer et al., 1972).

Benign tumoral types consisted of lipoma, vesical leiomyoma (Figure 5), and mammary adenoma. Diagnosed malignant cases consisted of simple mammary adenocarcinoma (Figure 6), solid adenocarcinoma, compact adenocarcinoma, hepatic cholangiocarcinoma, compact carcinoma,

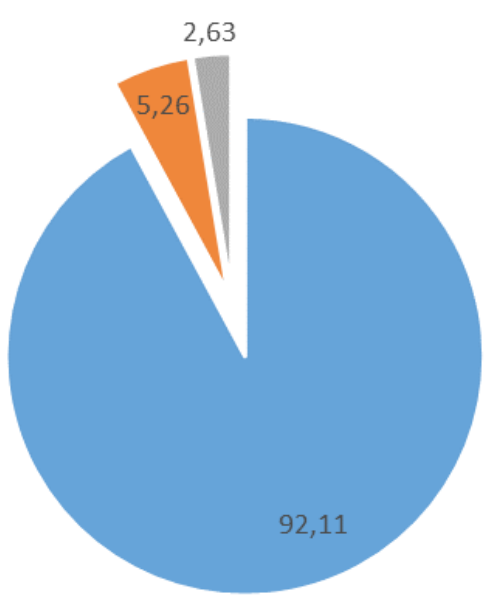

nammary tumors = Hepatic $\quad$ : Pulmonary

Figure 3. Case distribution according to the location of primary tumors, expressed as relative value (\%).

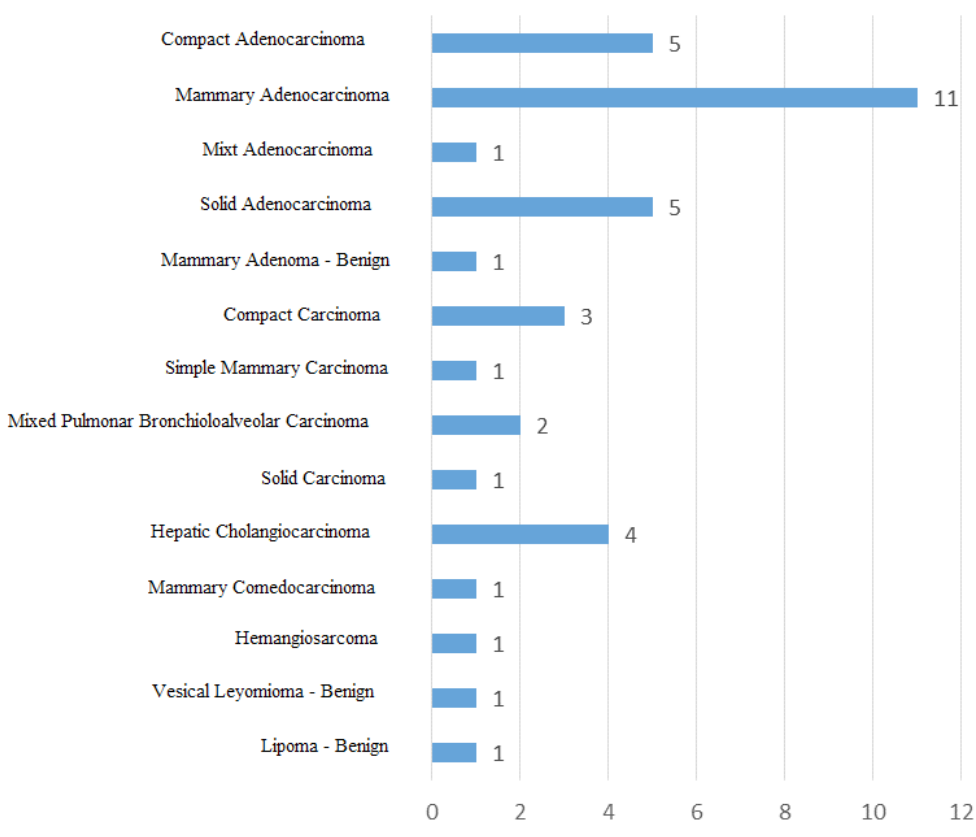

Figure 4. Distribution of tumor types, expressed as absolute value. 


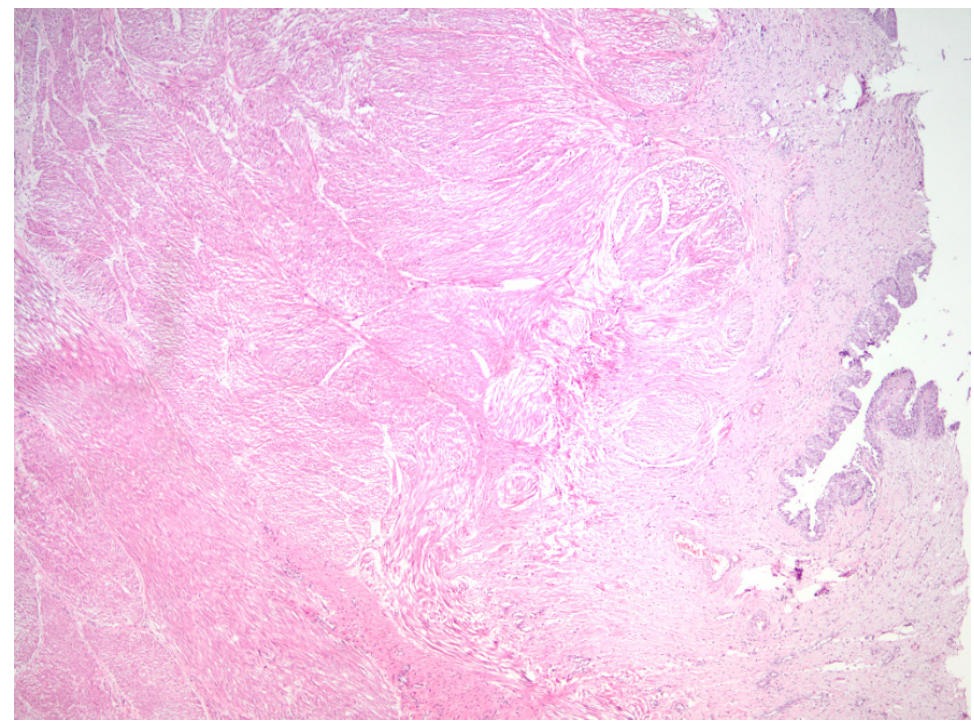

Figure 5. Histopathological exam $(500 \mu \mathrm{m})$, HE stain. Urinary bladder. Benign neoformation characterized by spindle-shaped cells of smooth appearance. Vesical leiomyoma. FMV Cluj-Napoca.

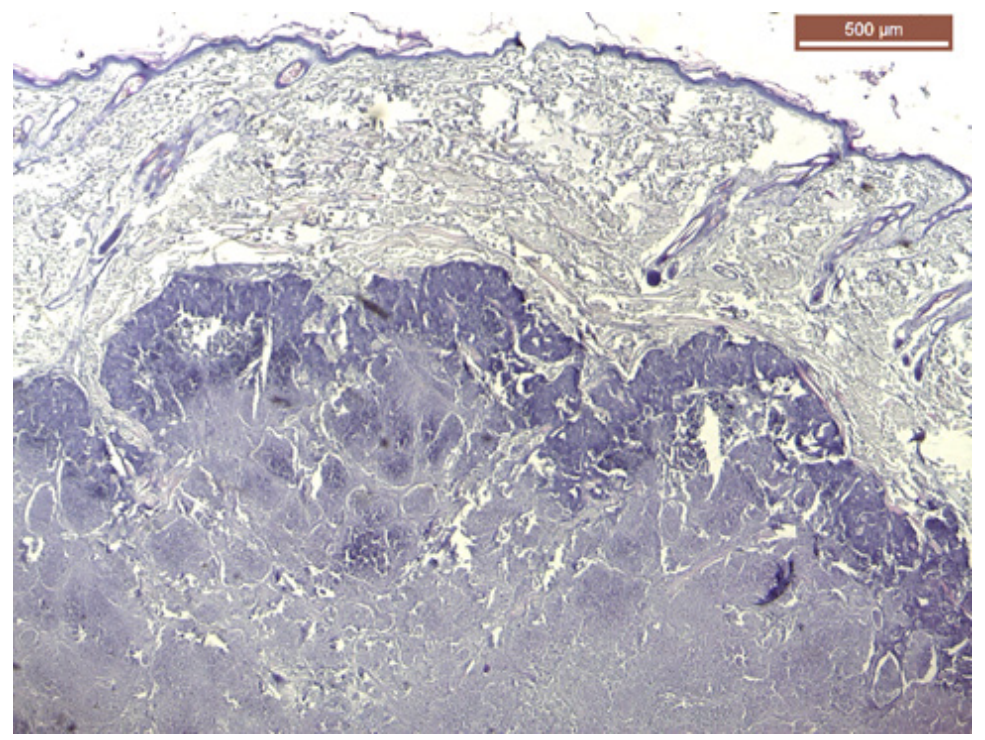

Figure 6. Histopathological exam $(500 \mu \mathrm{m})$, HEM stain. Mammary gland. Tumoral edges are constituted by active tumor cells in the tumoral proliferation process and infiltrating the dermis and hypodermis. Mammary adenocarcinoma. FMV Iași.

mixed pulmonar bronchioloalveolar carcinoma (Figure 7), hemangiosarcoma, mammary comedocarcinoma, solid carcinoma and mixed adenocarcinoma (Gavrilas, 2016; Owens, 1980).

The diagnosis of suspicious tumoral masses is set on clinical modifications found in organs (Rutteman, 2001; Vicario, 2010; Withrow et al., 2013). Necropsic examination can provide important additional data on tumoral processes, but it should always be followed by a histopathological exam for certainty (Cowell et al., 2006; Meuten, 2002; Withrow et al., 2013).

\section{Conclusions}

Benign tumoral types consisted of lipoma, vesical leiomyoma, and mammary adenoma. Diagnosed malignant cases consisted of simple mammary adenocarcinoma, solid adenocarcinoma, 


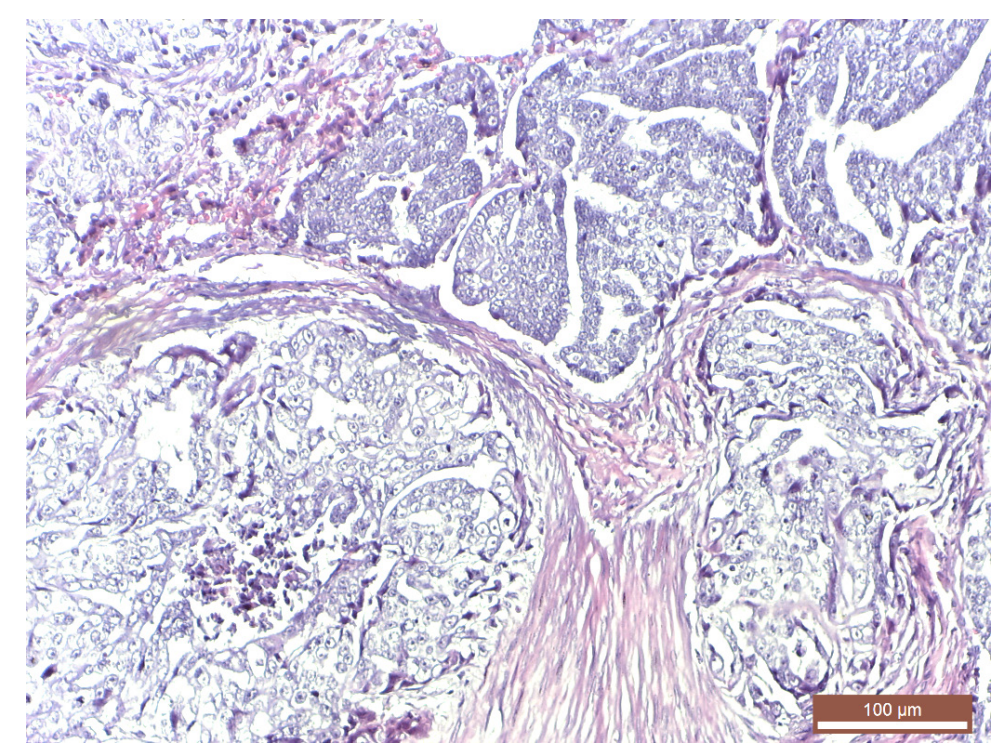

Figure 7. Histopathological exam $(100 \mu \mathrm{m})$, HE stain. Lung. Mixed bronchioloalveolar carcinoma. FMV Iași.

compact adenocarcinoma, hepatic cholangiocarcinoma, compact carcinoma, mixed pulmonar bronchioloalveolar carcinoma, hemangiosarcoma, mammary comedocarcinoma, solid carcinoma and mixed adenocarcinoma.

Necropsic examination can provide important additional data on tumoral processes, but it should always be followed by a histopathological exam for certainty.

Acknowledgments. This research did not receive any specific grant from funding agencies in the public, commercial, or not-for-profit sectors.

\section{References}

1. Argyle DJ, Khanna C (2007). Tumor biology and metastasis. In Withrow, S. J., Vail, D. M., eds. Withrow and MacEwen's small animal clinical oncology 4 th edn. St Louis, Saunders Elsevier, p. 31-53.

2. Baba A I (2002). Oncologie comparată. București, Editura Academiei Române

3. Balint E (2010). Hematologie Veterinară și Oncologie Comparată. București, Ed. Curtea Veche,

4. Barbara E (2008). Advances in feline oncology. Proceedings of the 33rd World Small Animal Veterinary Congress, Dublin, Ireland, p.508-509.

5. Biller B, Berg J, Garrett L, Ruslander D, et.al. (2016). AAHA Oncology Guidelines for Dogs and Cats, Veterinary Practice Guideline.

6. Cowell RL, Tyler RD, Meinkoth JH (2006). Guide Pratique de Cytologie et Hematologie du chien et du chat. Paris, Ed. Med'Com,
7. Dobson MJ, Lascelles BD (2011). BSAVA Manual of Canine and Feline Oncology, BSAVA.

8. Fidler IJ (2003). The pathogenesis of cancer metastasis: the 'seed and soil' hypothesis revisited. Nat Rev Cancer $3: 453-458$,

9. Gavrilaș E (2016). Investigații morfoclinice și imagistice privind procesele tumorale mamare și intraabdominale, precum și a unor metastaze pulmonare la pisică. Teză de Doctorat, Facultatea de Medicină Veterinară Iași,

10. Hanahan D, Weinberg RA (2011). Hallmarks of cancer: The next generation, Cell 144(5): 646-674

11. Hayes AA, Mooney S (1985). Feline mammary tumors, Vet Clin North Am Small Anim Pract 15:513-520,

12. Kusewitt DF, Rush LJ (2007). Neoplasia and tumor biology. In: Pathologic basis of veterinary disease, 4 th. St Louis Edition Mosby Elsevier.

13. Madewell B B, Theilea G H (1987). Tumors of the mammary gland. Veterinary cancer medicine, 2 nd ed. Lea and Lebiger, p. 327-343.

14. Mendoza M, Khanna C (2009). Revisiting the seed and soil in cancer metastasis. Int J Biochem Cell Biol 41(7):14521462 ,

15. Meuten DJ (2002). Tumors in domestic animals, ed 4, Ames, Iowa, Iowa State University Press,

16. Misdorp W, Romijin A, Hart AAM (1991). Feline mammary tumors: A case-control study of hormonal factors, Anticancer Res 11:1793.

17. Owens L (1980). Classification of tumors in domestic animals, Geneva, World Health Organization.

18. Rutteman GR, Withrow SJ, Mac Ewen EG (2001). Tumors of the mammary gland. In : Small animal clinical oncology, Withrow SJ, MacEwen EG editors. 3rd edition. Philadelphia, WB Saunders. 
19. Vicario PC (2010). Clinical staging in oncology, Proceedings of the Southern European Veterinary Conference - SEVC Barcelona, Spain.

20. Weijer K, Head KW, Misdorp W, et al (1972). Feline malignant mammary tumors. I. Morphology and biology: some comparisons with human and canine mammary carcinomas, J Natl Cancer Inst 49:1697-1704.

21. Withrow JS, Vail MD, Page LR (2013). Small Animal Clinical Oncology, $5^{\text {th }}$ Edition, Elsevier. 